\title{
Tissue Zinc Concentration in Prostate Cancer: Relationship with Prostate Specific Antigen and Gleason Score in a Cohort of Nigerian Men
}

\author{
Martin Igbokwe', Ayo Salako ${ }^{1}$, Tajudeen Badmus ${ }^{1}$, Eusebius Obiajunwa ${ }^{2}$, \\ Olalekan Olasehinde ${ }^{3}$, Chiamaka Igbokwe ${ }^{4}$, Rotimi David ${ }^{1}$
}

${ }^{1}$ Urology Division, Department of Surgery, Obafemi Awolowo University Teaching Hospitals Complex, Ile-Ife, Nigeria. ${ }^{2}$ Centre for Energy, Research and Development, Obafemi Awolowo University, Ile-Ife, Nigeria. ${ }^{3}$ General Surgery Unit, Department of Surgery, Obafemi Awolowo University Teaching Hospitals Complex, Ile-Ife, Nigeria. ${ }^{4}$ Dental Unit, Federal Medical Centre, Abuja, Nigeria.

\begin{abstract}
Introduction: Prostate cancer (PCa) is the commonest maliganacy among men of African descent. The possible role of trace elements like Zinc in its aetiogenesis and disease severity remains controversial. This paper aims to identify the relationship between tissue zinc concentration and the occurrence of prostate cancer. And to identify the relationship between the tissue zinc concentration and the disease severity (using the prostate specific antigen (PSA) and Gleason scores (GS)). Methodology: A cross-sectional study of 41 consecutive consenting men with histologically confirmed PCa and 41 age-matched controls. Toe-nail clippings were obtained from both groups and assayed for zinc using the Particle induced X-ray emission (PIXE) technique. Zinc concentrations were compared between cases and controls. A correlation analysis was performed to determine relationship between Zinc concentration and disease severity (PSA and GS). Results: Forty one men each were recruited in the Prostate cancer and control groups for this study. PCa group had a mean age of $72.83 \pm 7.06$ years while the control group was $70.73 \pm 6.40$ years. There was statistically significant higher toe-nail $\mathrm{Zn}$ concentration among Prostate cancer patients than controls $(\mathrm{P}=0.028, \mathrm{t}=2.28, \mathrm{df}=40)$. The mean PSA values among the Prostate cancer group was $46.10 \pm 40.62 \mathrm{ng} / \mathrm{ml}$ and mode GS was 8 . There was neither a correlation between toe-nail $\mathrm{Zn}$ concentration and serum PSA levels ( $p=0.386$ ) nor with the GS. Conclusion: This study found a statistically significant higher toe-nail Zn concentration among men with PCa compared with age-matched controls. There was however no correlation between toe-nail $\mathrm{Zn}$ concentration and the serum prostate specific antigen or Gleason score.
\end{abstract}

Keywords: Prostate cancer- Zinc- Particle-induced X-ray emission- Gleason score- Prostate specific antigen

\section{Introduction}

Prostate Cancer $(\mathrm{PCa})$ is the commonest urologic malignancy [1-2]. The last few decades have witnessed an increase in the burden of PCa globally, an increase that is predominant among men of African decent [1, 3-5]. In Nigeria, $\mathrm{PCa}$ is the leading cause of cancer related deaths in men accounting for $11 \%$ of all male cancers in Nigerian men $[1,6]$. This high mortality is attributed to the fact that greater than $80 \%$ of $\mathrm{PCa}$ cases in our environment present with advanced or metastatic disease hence most only benefit from palliative androgen ablation therapy [7-8].

Despite intense research on this subject, the aetiology of prostate cancer is still very poorly understood. Postulated aetio-pathogenic factors for PCa include advanced age, genetic factors, chronic prostatitis, exposure to androgens, estrogens, leptin, vitamin D, sexually transmitted infections, dietary fats, obesity, alcohol and deficiency of trace elements like zinc and selenium [9]. The role of trace elements in the occurrence of PCa has been the focus of much research efforts over the last two decades [10-13].

\section{Corresponding Author:}

Dr. Igbokwe Martin

Urology Division, Department of Surgery, Obafemi Awolowo University Teaching Hospitals Complex, Ile-Ife, Nigeria.

Emails: martini4life@yahoo.com,martini4life99@gmail.com 
One of such trace elements is Zinc ( $\mathrm{Zn})$ which is an essential trace element that is ubiquitous in the human body. It is an endogenous inhibitor of the enzymatic activity of prostate-specific antigen (PSA) which is a key factor responsible for the disturbance of the normal homeostasis of insulin-like growth factor 1 (IGF-1) and known to have a role in aetio-pathogenesis of prostate cancer [14-15]. Zinc is predominantly obtained from diet and it is concentrated in blood, nails, hair and other living tissues including the prostate gland. The prostate gland is known to concentrate $\mathrm{Zn}$ up to 10 times more than in other tissues. Studies evaluating $\mathrm{Zn}$ levels in patients with PCa showed significantly lower (approx. 2-3-fold) zinc concentrations in the prostatic tissue that are affected by the neoplastic process compared to healthy prostatic tissue in the same subject [15-16]. Hence there is an uneven distribution of $\mathrm{Zn}$ in the prostate gland of patients with PCa [15]. Cohort studies have demonstrated that dietary $\mathrm{Zn}$ intake or plasma $\mathrm{Zn}$ concentrations are inversely associated with cancers and mortality risk [17-18]. Kristal et al found that the intake of Zn supplements was associated with a reduced Pca [19] risk while the Vitamin and Lifestyle (VITAL) cohort study revealed that supplemental $\mathrm{Zn}$ intake did not influence Pca risk but reduced risk of advanced Pca [20]. In North Carolina, Wagner et al deduced that areas with lower soil zinc content had higher prevalence of $\mathrm{PCa}$ [21]. In contrast however, Zhang et al showed that long-term use of zinc supplements increased the risk of $\mathrm{PCa}$ [22].

Studies have also attempted further to demonstrate the effect of the tissue $\mathrm{Zn}$ concentration on the severity of $\mathrm{PCa}$ by comparing with serum PSA values and Gleason score. Vartsky et al showed an inverse relationship between tissue $\mathrm{Zn}$ concentration and Prostate Specific Antigen (PSA) with elevated PSA and reduced prostatic $\mathrm{Zn}$ increasing the chances of PCa [23]. Cortesi et al found that the lower the local prostatic $\mathrm{Zn}$ concentration, the higher the chances of PCa and the worse the Gleason score [24].

Most of the earlier studies in this dormain made use of prostatic tissue to assess tissue $\mathrm{Zn}$ concentration and found there is uneven distribution of $\mathrm{Zn}$ in malignant prostatic tissue. This study therefore aims to assess toe-nail clippings for tissue $\mathrm{Zn}$ concentration in men with $\mathrm{PCa}$ to ensure a reliable representation of tissue $\mathrm{Zn}$ concentration. The relative ease of sample collection, the fact that it provides a more stable measure of $\mathrm{Zn}$ status than serum and prostatic tissue, coupled with a good correlation of $\mathrm{Zn}$ levels assayed years apart, aids its preference [12, 25].

The increasing burden of PCa as well as the more aggressive variants of the disease in men of African descent have necessitated this study on the role of $\mathrm{Zn}$ in the aetiopathogenesis of PCa and its correlation with PSA and gleason's score. This study was aimed to determine the correlation between toe-nail Zn concentration, Serum PSA values and Gleason score in patients with Prostate cancer.

\section{Materials and Methods}

\section{Patients}

This was a prospective hospital-based comparative study conducted in the urology unit of the Obafemi Awolowo University Teaching Hospitals Complex which is a Federal tertiary institution in Ile-Ife, Osun state, South-western Nigeria over a 1-year (September 2017-August 2018). Consecutive patients with histopathologically confirmed prostate cancer following prostate biopsy were recruited. Also age-matched controls without prostate cancer were recruited for comparison. The histological appraisal included the gleason score. A single pathologist was responsible for appraisal of all prostatic biopsy specimens during the study period in order to avoid inter-observer variations.

Exclusion criteria included:

1. Patients who were found to be on Zinc supplements.

2. Patients who had small bowel resection or any bowel pathology which may affect zinc absorption.

3. Patients who were indulging in application of toe-nail polish or treatment which alter toe-nail zinc concentration.

4. Patients with obvious nail diseases which could alter nail zinc concentration.

5. Patients already on anti-androgens or any form of hormonal ablation

\section{Sample Size Determination}

The Leslie-Fischer's formula for minimum sample size estimation was used to determine the sample size for this study [26-27]:

$$
\mathrm{n}=\mathrm{z}^{2} \mathrm{pq} / \mathrm{d}^{2}
$$

Where:

$\mathrm{n}=$ Minimum sample size

$\mathrm{z}=$ This is 1.96 , when the confidence interval is $95 \%$

$\mathrm{p}=$ Estimated prevalence of prostate cancer in our community.

A 5-year review of the hospital day-case surgery records between January 2009 and December 2013, revealed that of a total of 5760 procedures/surgeries, 650 prostate biopsies were done and 144 cases were histologically diagnosed with prostate cancer during this period. Hence a prevalence of $2.5 \%$ of the total patients seen during this period was recorded.

$$
\begin{aligned}
& \text { Thus, } \mathrm{p}=0.025 \\
& \begin{aligned}
\mathrm{q} & =1.0-\mathrm{p} \\
& =1.0-0.025=0.975 \\
\mathrm{~d} & =\text { Desired maximum allowable margin of error. }
\end{aligned}
\end{aligned}
$$
A maximum of

$5 \%$ margin of error will be allowed in this study

Therefore, 
Considering an attrition rate of $10 \%$, the total sample size became:

$N=100 \times 37 / 90=41$ patients

Thus, a sample size of 41 patients was used for cases and 41 for controls.

\section{Methodology}

Patients presenting to the out-patient clinic with signs and symptoms suggestive of prostate cancer had thorough history taken, general physical examination (including DRE) and investigations (including PSA) done. Patients suspected to have PCa were subjected to extended sextant trans-rectal digitally guided prostate biopsy under caudal anaesthesia ( $85 \%$ of prostate biopsies during the study period were done by the researcher). Prostatic biopsy specimens were transported to the histopathology laboratory in $10 \%$ buffered formalin solution. Adesignated Senior registrar under the supervision of a consultant was responsible for evaluating ALL prostatic specimens to confirm $\mathrm{PCa}$ and assign Gleason scores. Individuals with histological confirmation of prostate cancer were recruited for this study. The subject information sheet (Appendix I) was administered to the subject and informed consent was obtained before recruitment for this study. Patients' demographic characteristics, symptoms and investigation results were recorded in a pre-designed proforma (including the Gleason score) (Appendix II).

Consenting subjects had approximately $0.5 \mathrm{~cm}$ long toe nail excised from the big toe and placed in a labelled plain bottle before storage in the refrigerator at $0-4^{\circ} \mathrm{C}$.

Consecutive age-matched males presenting to the urological or general surgery outpatient clinics with a normal DRE finding and normal PSA were also recruited as controls. The controls had their details entered into the same proforma (Appendix II) and subsequently had toe nail excised for $\mathrm{Zn}$ assay.

The respective specimen containers were labelled alphabetically in order to ensure confidentiality to the patient/control and blinding to the Zinc analyst.

Flow chart to guide the research activities was followed.

Case files of both cases and controls were labelled to avoid double count.

\section{Laboratory and clinical analysis}

The labelled toe-nails were transported to the Centre for Energy Research and Development (CERD), ObafemiAwolowo University, Ile-Ife, where zinc concentrations were determined using Particle-induced X-ray emission (PIXE) technique. The PIXE experiment was performed using a $2.5 \mathrm{MeV}$ proton beam obtained from CERD ion beam analysis facility, a 1.7 MV Pelletron accelerator, model NEC 5SDH.

\section{Washing of nail specimen}

The nail specimen were washed to eliminate contaminants which may contain various minute concentrations of trace elements and hence give a false result. Washing was done with room temperature distilled water and dried at room air.

\section{Calibration of PIXE System}

The PIXE set-up was calibrated using some pure element standards and NIST geological standard, NBS 278. The International Atomic Energy Agency (IAEA) Animal Bone standard (IAEA-H-5) was used for the determination of the $\mathrm{H}$-value which was subsequently used for the quantification of the nail samples results and also to assure the accuracy of the experimental procedure.

\section{Zinc concentration in Nails}

To obtain the $\mathrm{Zn}$ concentration in the various samples, the nails were mounted in the sample holder in the scattering chamber and irradiated for 10-20 minutes with the proton beam. The beam spot was $4 \mathrm{~mm}$ in diameter and of low current (3-6 nA). A CamberraSi (Li) X-ray detector with associated pulse processing electronics interfaced to a PC were used for the X-ray data acquisition.

The computer code GUPIXWIN was used for the analysis of the PIXE data. The $\mathrm{Zn}$ concentrations in the samples were obtained, tabulated and analysed.

\section{Data Analysis}

The data was entered and analysed using SPSS statistical software version 20. Univariate analysis was utilized to determine the sociodemographic data of the subjects, using percentages and means (with standard deviation).

The independent T-test was employed to determine if there was any significant difference in the toe-nail zinc concentration between the study group and control using 0.05 level of significance $(\mathrm{P}<0.05)$. The $95 \%$ confidence interval was also put in place.

Pearson correlation was used to determine the relationship between tissue $\mathrm{Zn}$ concentration and the PSA as well as GS respectively.

\section{Institutional Ethical Committee Approval}

This research was performed in accordance with the ethical standards laid down in the 1964 declaration of Helsinki. Approval was obtained from the ethical committee of the Obafemi Awolowo University Teaching Hospitals Complex (Appendix I and Appendix II). Informed consent was also obtained from all suitable patients before being included in the study. The study was conducted at no additional cost to the patient. The cost of tissue $\mathrm{Zn}$ assessment was undertaken partly by the investigator with co-sponsorship through the Obafemi Awolowo University Teaching Hospitals Complex, Ile-Ife research grant for residents.

\section{Results}

Eighty five men underwent Prostate biopsy during the study period out of which forty-one $(41 ; 48.25 \%)$ had histologically confirmed prostate cancer and were recruited for this study. Also, forty-one age-matched adult males (controls) were recruited for this study, all of them 
were suitable for analysis.

Socio-Demographic Characteristics of Study Population

The age distribution of patients in the PCa group showed a range from 56 to 90 years with mean of $72.83 \pm 7.06$ years. The peak age incidence in the PCa group was in the 8 th decade (71-80 years) (Table 1$)$.

Similar to the PCa group, the age range of patients in the control group was between 55 to 88 years with a mean age of $70.73 \pm 6.40$ years. The age distribution of patients in the control group was also statistically similar to those in the study group as depicted in Table 1. There was no statistically significant difference in the ages of the PCa group vs controls $(\mathrm{t}=3.471, \mathrm{p}>0.05)$.

Regarding occupational distribution, about half of the patients in the PCa group were retirees while active civil servants, business men and clergy accounted for the rest.

All the patients in this study were domicile in the South-western part of Nigeria with $39 ; 95 \%$ of the PCa group resident in Ile-Ife and 37:90.2\% of the control group resident in Ile-Ife.

\section{Biochemical and Histopathological Characteristics of} Study Population

Among the Prostate cancer patients the PSA values ranged from 12.0 to $177 \mathrm{ng} / \mathrm{ml}$ with a mean of $46.10 \pm 40.62$, median $34 \mathrm{ng} / \mathrm{ml}$. As shown in Table 2 about $70 \%$ of men with PCa had PSA values greater than $20 \mathrm{ng} / \mathrm{ml}$. On the other hand, the control group had PSA range of 1.8 to $6.5 \mathrm{ng} / \mathrm{ml}$ with a mean of $3.88 \pm 1.58$. There was a statistically significant difference between the mean of the two groups $(\mathrm{p}=0.001)$.

The Gleason score of $\mathrm{PCa}$ patients in this study ranged from 6 to 10 with a mode Gleason score of 8 . Forty one percent of patients in the study group had a Gleason score of 8 (Figure 1).

\section{Toe-Nail Zn Concentration among Study Groups}

The toe-nail $\mathrm{Zn}$ concentration among PCa patients in this study ranged from $38.4-594.6 \mu \mathrm{g} / \mathrm{g}$ with a median and inter quartile range of 116.5 and $256.47 \mu \mathrm{g} / \mathrm{g}$ respectively while the among the controls the values ranged from 56.7 to $313.8 \mu \mathrm{g} / \mathrm{g}$ with a median and inter-quartile

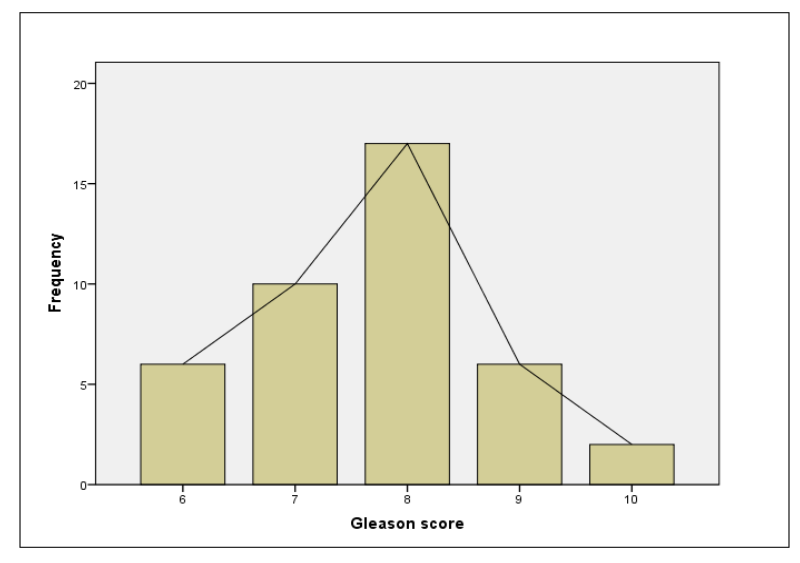

Figure 1. Gleason Score Distribution among Men with $\mathrm{PCa}$

range of 96.1 and $29.4 \mu \mathrm{g} / \mathrm{g}$ respectively (Figures 2 and 3). Eighteen men (44\%) with PCa in this study had toe-nail $\mathrm{Zn}$ concentration $<100 \mu \mathrm{g} / \mathrm{g}$ and the remaining $56 \%$ had $\mathrm{Zn}$ values of $>100 \mu \mathrm{g} / \mathrm{g}$. Among the controls, 29 men (70.7\%) had $\mathrm{Zn}$ concentration below $100 \mu \mathrm{g} / \mathrm{g}$ and 12 (29.3\%) had $\mathrm{Zn}$ concentration $>100 \mu \mathrm{g} / \mathrm{g}$.

There was statistically significant higher toe-nail Zn concentration among Prostate cancer patients than controls $(\mathrm{P}=0.028, \mathrm{t}=2.28, \mathrm{df}=40)$ (Figure 4).

\section{Correlation Of Toe-Nail Zn Concentration With Serum Psa}

There was a weak relationship between the toe-nail $\mathrm{Zn}$ concentration and the PSA values among men with PCa as depicted in the scatter plot below. Using the Pearson correlation, it was found to be statistically insignificant $(\mathrm{p}=0.386)$ (Figure 5).

However, among the controls there was a statistically significant correlation between $\mathrm{Zn}$ concentration and serum PSA $(p=0.04)$.

Correlation Between Toe-Nail Zn Concentration and Gleason Score

There was an inverse correlation between the toe-nail $\mathrm{Zn}$ concentration in PCa patients and their Gleason score

Table 1. Sociodemographic Characteristics of Study Population

\begin{tabular}{|c|c|c|c|}
\hline Variables & Pca Group & Control Group & Statistics \\
\hline \multicolumn{4}{|l|}{ Age, years } \\
\hline Mean \pm SD & $72.83 \pm 7.06$ & $70.73 \pm 6.40$ & $\mathrm{p}=0.250$ \\
\hline \multicolumn{4}{|c|}{ Age distribution (years), n (\%) } \\
\hline $51-60$ & $3(7.3)$ & $3(7.3)$ & \\
\hline $61-70$ & $12(29.3)$ & $13(31.7)$ & \\
\hline $71-80$ & $20(48.8)$ & $19(46.4)$ & $\mathrm{t}=3.471$ \\
\hline $81-90$ & $6(14.6)$ & $6(14.6)$ & $\mathrm{p}>0.05$ \\
\hline \multicolumn{4}{|l|}{ Occupation } \\
\hline Retired & $21(51.2)$ & $13(31.7)$ & \\
\hline Civil servant & $12(29.3)$ & $19(46.4)$ & \\
\hline Business man & $6(14.6)$ & $9(21.9)$ & \\
\hline Clergy & $2(4.9)$ & $0(0)$ & \\
\hline
\end{tabular}




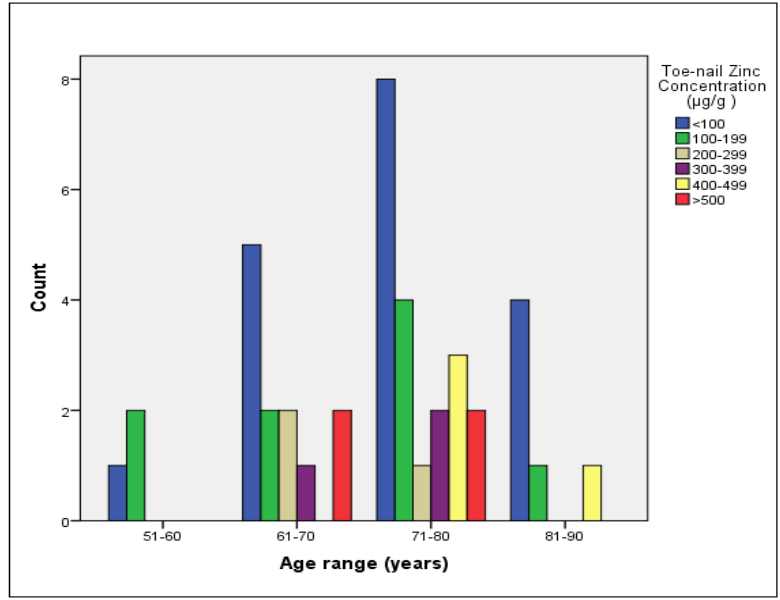

Figure 2. Toe-nail Zinc Concentration Distribution among Men with PCa

in this study. This relationship was however found to be statistically insignificant $(\mathrm{p}=0.192)$ (Figure 6).

\section{Discussion}

Prostate cancer is the a leading cause of cancer related mortality in men worldwide. The role of $\mathrm{Zn}$ in the aetiogenesis of PCa has been a point of debate for years. This research found that tissue Zinc concentration was significantly higher among men with PCa compared to age-matched controls. There was also no statistically significant correlation between the $\mathrm{Zn}$ concentration and the PSA or Gleason score.

The peak age among the study population being between 71 and 80 years validates the fact that Pca is a disease of elderly men as found in other local publications $[6,7,28]$. The succesful age-matching of patients in the two groups as shown by the near equal mean ages reflects the similarity between the groups. It was however noted that PCa could not have been completely excluded among the controls by DRE and PSA only (see

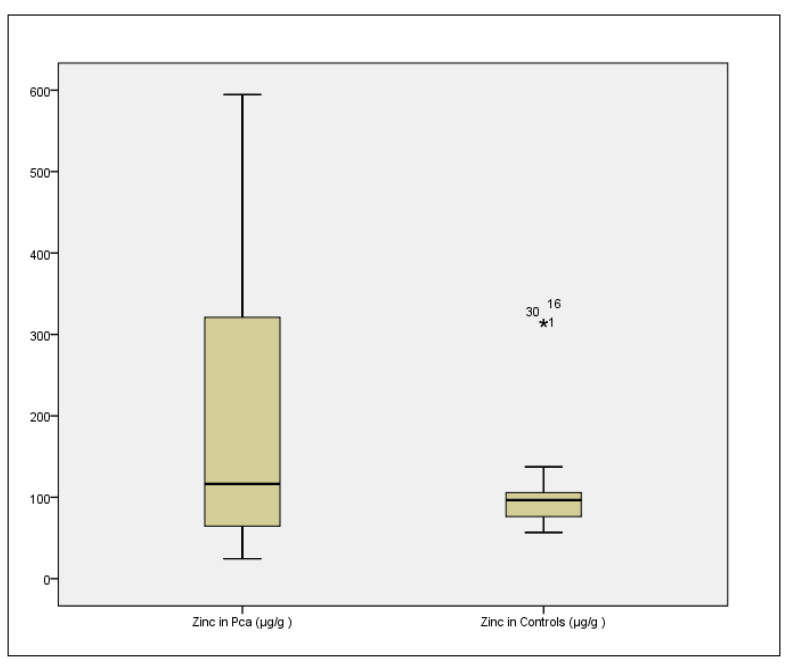

Figure 4. Distribution of toe-nail Zinc Concentration among PCa Patients and Controls

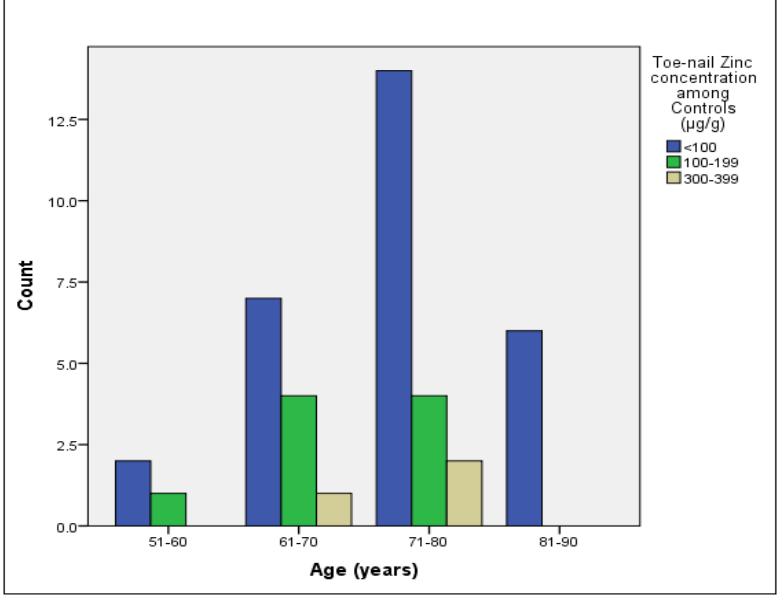

Figure 3. Toe-nail Zinc Concentration Distribution among age-matched Controls

limitations). This similarity in age coupled with the fact that men in both groups were domicile in the same part of the country with similar environmental exposure provides the clinical equipoise needed for comparison.

From the findings in this study, there is a comparable toe-nail $\mathrm{Zn}$ concentration among the control group and community-based findings by Ayodele et al from Kano in Northern Nigeria [29]. This study further established that the average toe-nail $\mathrm{Zn}$ concentration among men with PCa in Ile-Ife was significantly higher than PCa-free age-matched men. This finding may in essence suggest that increased toe-nail and tissue $\mathrm{Zn}$ concentration may be a risk factor for PCa. A few international researchers have similarly documenteds increased $\mathrm{Zn}$ in diet and tissue as a risk factor for the development of $\mathrm{PCa}$ [22, 30-31]. Our findings are further corroborated by researches by Mahmoud et al who found a non-linear increase in risk of prostate cancer with increasing zinc tissue concentration and intake which was not statistically significant among the case-control group. Mahmoud et al in a meta-analysis of 17 studies also showed there was a $24 \%$ increase risk of

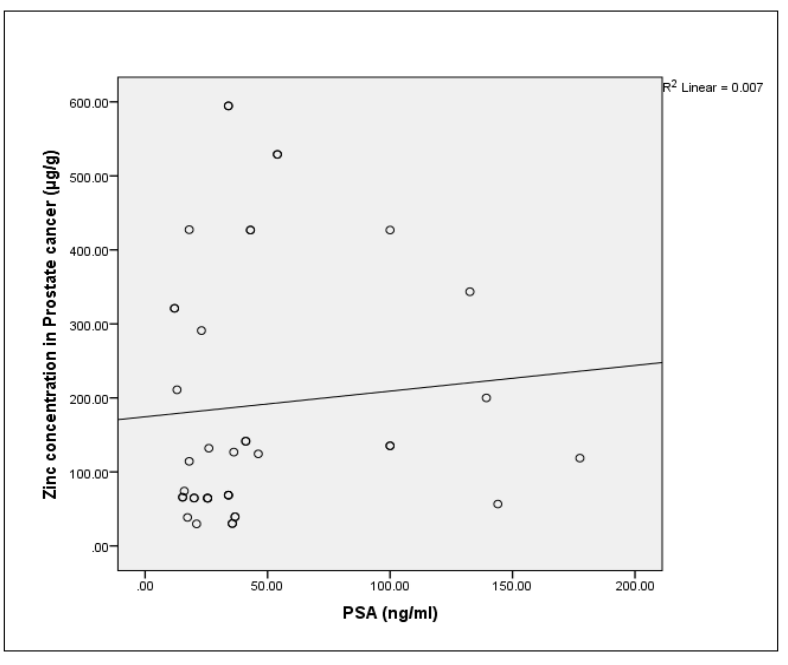

Figure 5. Relationship of Serum PSA with Toe-nail Zn Concentration in PCa Patients 
Table 2. PSA Distribution among PCa and Control Groups

\begin{tabular}{ccccccc}
\hline & \multicolumn{3}{c}{ PCa Group } & \multicolumn{4}{c}{ Control Group } \\
\hline & Minimum & Maximum & Mean & Minimum & Maximum & Mean \\
PSA $(\mathrm{ng} / \mathrm{ml})$ & 12 & 177 & $46.10 \pm 40.62$ & 1.8 & 6.5 & $3.88 \pm 1.58$ \\
\hline
\end{tabular}

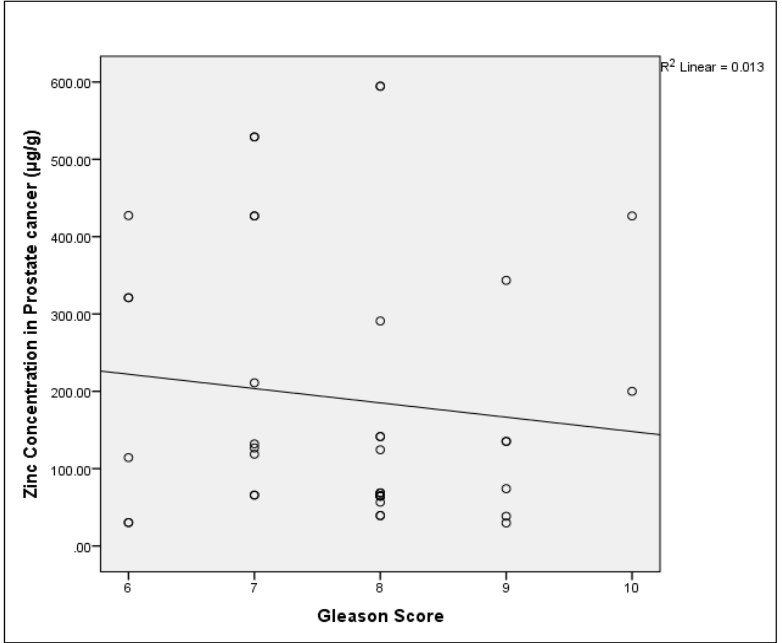

Figure 6. Relationship of Gleason Score with Toe-nail $\mathrm{Zn}$ Concentration in PCa Patients

prostate cancer associated with increased zinc intake measured in serum [32] and hair/nail [33].

This study found a marginally positive correllation between tissue $\mathrm{Zn}$ concentration and PSA among PCa patients though it was not statistically significant. Considering that there was positive correlation between tissue $\mathrm{Zn}$ concentration and PSA values among controls in this study suggests that a longer term follow up of these individuals to identify who develops PCa can be a pointer to $\mathrm{Zn}$ either as an aetio-pathogenic agent in $\mathrm{PCa}$ or a protective element. Vartsky and colleagues found a positive correlation between tissue $\mathrm{Zn}$ concentration and PSa in PCa patients and suggested that combination of these two investigations may increase the specificity of diagnosing PCa without prostate biopsy [23].

Finally, the weak negative correlation between toenail $\mathrm{Zn}$ concentration and Gleason score may further suggest that among men with $\mathrm{PCa}$, the more poorly differentiated tumours are associated with lower tissue $\mathrm{Zn}$ concentration. Zhang et al in their study among a Chinese population found no relationship between tissue Zn concentration and the Gleason score in men with PCa [22] while Kolonel et al and other researchers have found higher Gleason score among men with high $\mathrm{Zn}$ intake and tissue concentration [30-31] although these were carried out among pre-drominantly caucasian populations.

In conclusion, there is a significantly higher toe-nail $\mathrm{Zn}$ concentration among men with $\mathrm{PCa}$ (median -116.5 $\mu \mathrm{g} / \mathrm{g})$ compared with age-matched controls $(96.1 \mu \mathrm{g} / \mathrm{g})$ in Obafemi Awolowo University Teaching Hospitals Complex, Ile-Ife, Osun State $(\mathrm{P}=0.028, \mathrm{t}=2.28, \mathrm{df}=40)$.

There was a marginal positive correlation between the toe-nail $\mathrm{Zn}$ concentration and the PSA values among men with PCa .this was however not statistically insignificant $(\mathrm{p}=0.386)$.

Finally, there was a weak inverse correlation between the toe-nail $\mathrm{Zn}$ concentration and the Gleason score in men with PCa. This was also statistically insignificant $(\mathrm{p}=0.192)$.

\section{Recommendation}

1. There is a need for current analysis of the soil and staple food zinc content in Ile-Ife. And also an estimate of zinc consumed in diet among men. This could serve as a background for future recommendations on dietary discretions towards prevention or development of PCa.

2. A longer term follow up of controls with yearly toe-nail $\mathrm{Zn}$ assay to identify those that develop Pca in the future may help shed more light on the role of $\mathrm{Zn}$ in the aetio-pathogenesis of $\mathrm{PCa}$ in a black population.

\section{Acknowledgments}

We would like to acknowledge the members of the Urology Unit, Obafemi Awolowo University Teaching Hospitals Complex, Ile-Ife who participated in sample collection and other support during the period of the research. They include Drs Yinka Laoye, Chigozie Onyeze, Rereloluwa Babalola and Ibrahim Akinbola.

\section{References}

1. Ogunbiyi J, Shittu O. Increased Incidence of Prostate Cancer in Nigeria. Journal of National Medical Association. 1999;91:159-64.

2. Mohammed A, Nwana E, Anjorin A. Histological pattern of prostatic diseases in Nigerians. African Journal of Urology. 2005;11(1):33-8.

3. Jedy-Agba E, Curado MP, Ogunbiyi O, Oga E, Fabowale T, Igbinoba F, et al. Cancer incidence in Nigeria: A report from population-based cancer registries. Cancer Epidemiology. 2012 Oct;36(5):e271-e278. https://doi.org/10.1016/j. canep.2012.04.007

4. Badmus T, Adesunkanmi A, Yusuf B, Oseni G, Eziyi A, Bakare $\mathrm{T}$, et al. Burden of prostate cancer in southwestern Nigeria. Urology. 2010;76:412-6.

5. Osegbe D. Prostate cancer in Nigerians: facts and nonfacts. The Journal of urology. 1997;157:1340-3.

6. Ikuerowo SO, Omisanjo OA, Bioku MJ, Ajala MO, Nonyelim VP, Esho JO. Prevalence and characteristics of prostate cancer among participants of a community-based screening in Nigeria using serum prostate specific antigen and digital rectal examination. Pan African Medical Journal. 2013;15. https://doi.org/10.11604/pamj.2013.15.129.2489

7. Ifere G, Abebe, Ananaba. Emergent trends in the reported incidence of prostate cancer in Nigeria. Clinical Epidemiology. 2012 01;:19. https://doi.org/10.2147/clep. s23536

8. Salako A, Arowolo O, Omonisi E, Adisa A, Titiloye N, 
Adelusola K. Incidental carcinoma of the prostate gland presenting with initial manifestation of disseminated intravascular coagulopathy (dic) in a middle aged man: a case report. Cases Journal. 2009;2(1):144. https://doi. org/10.1186/1757-1626-2-144

9. Wein A, Kavoissi L, Novick A, Partin A, Peters C. CampbellWalsh Urology 9th Edition. Philadelphia, USA: Saunders Elsevier. 2007.

10. Gonzalez A, Peters U, Lampe JW, White E. Zinc Intake From Supplements and Diet and Prostate Cancer. Nutrition and Cancer. 200902 21;61(2):206-215. https://doi. org/10.1080/01635580802419749

11. Banas A, Kwiatek WM, Banas K, Gajda M, Pawlicki B, Cichocki T. Correlation of concentrations of selected trace elements with Gleason grade of prostate tissues. JBIC Journal of Biological Inorganic Chemistry. 201005 25;15(7):11471155. https://doi.org/10.1007/s00775-010-0675-5

12. Gonzalez A, Peters U, Lampe JW, Satia JA, White E. Correlates of Toenail Zinc in a Free-Living U.S. Population. Annals of Epidemiology. 2008 01;18(1):74-77. https://doi. org/10.1016/j.annepidem.2007.07.100

13. Franz M, Anderle P, Bürzle M, Suzuki Y, Freeman M, Hediger M, Kovacs G. Zinc transporters in prostate cancer. Molecular Aspects of Medicine. 2013 04;34(2-3):735-741. https://doi.org/10.1016/j.mam.2012.11.007

14. Sutkowski DM, Goode RL, Baniel J, Teater C, Cohen P, McNulty AM, Hsiung HM, Becker GW, Neubauer BL. Growth Regulation of Prostatic Stromal Cells by ProstateSpecific Antigen. JNCI Journal of the National Cancer Institute. 1999 Oct 06;91(19):1663-1669. https://doi. org/10.1093/jnci/91.19.1663

15. Daragó A, Sapota A, Matych J, Nasiadek M, SkrzypińskaGawrysiak M, Kilanowicz A. The correlation between zinc and insulin-like growth factor 1 (IGF-1), its binding protein (IGFBP-3) and prostate-specific antigen (PSA) in prostate cancer. Clinical Chemistry and Laboratory Medicine. 2011 01 01;49(10). https://doi.org/10.1515/cclm.2011.651

16. Sapota A, Daragó A, Taczalski J, Kilanowicz A. Disturbed homeostasis of zinc and other essential elements in the prostate gland dependent on the character of pathological lesions. BioMetals. 200907 23;22(6):1041-1049. https:// doi.org/10.1007/s10534-009-9255-y

17. Leone N, Courbon D, Ducimetiere P, Zureik M. Zinc, Copper, and Magnesium and Risks for All-Cause, Cancer, and Cardiovascular Mortality. Epidemiology. 2006 05;17(3):308314. https://doi.org/10.1097/01.ede.0000209454.41466.b7

18. Wu T. Serum iron, copper and zinc concentrations and risk of cancer mortality in US adults. Annals of Epidemiology. 2004 03;14(3):195-201. https://doi.org/10.1016/s10472797(03)00119-4

19. Kristal A, Stanford J, Cohen J, Wicklund K, Patterson $\mathrm{R}$. Vitamin and mineral supplement use is associated with reduced risk of prostate cancer. Cancer Epidemiol Biomarkers Prev. 1999;8(10):887-92.

20. Gonzalez A, Peters U, Lampe JW, White E. Zinc Intake From Supplements and Diet and Prostate Cancer. Nutrition and Cancer. 200902 21;61(2):206-215. https://doi. org/10.1080/01635580802419749

21. Wagner SE, Burch JB, Hussey J, Temples T, Bolick-Aldrich S, Mosley-Broughton C, Liu Y, Hebert JR. Soil zinc content, groundwater usage, and prostate cancer incidence in South Carolina. Cancer Causes \& Control. 2008 Oct 24;20(3):345353. https://doi.org/10.1007/s10552-008-9248-0

22. Zhang Y, Coogan P, Palmer JR, Strom BL, Rosenberg L. Vitamin and mineral use and risk of prostate cancer: the case-control surveillance study. Cancer Causes \& Control.
2008 Dec 18;20(5):691-698. https://doi.org/10.1007/s10552008-9282-y

23. Vartsky D, Shilstein S, Bercovich A, Huszar M, Breskin A, Chechik R, Korotinsky S, Malnick S, Moriel E. Prostatic Zinc and Prostate Specific Antigen: An Experimental Evaluation of Their Combined Diagnostic Value. Journal of Urology. 2003 Dec;170(6):2258-2262. https://doi. org/10.1097/01.ju.0000095795.86327.b8

24. Cortesi M, Fridman E, Volkov A, Shilstein SS, Chechik R, Breskin A, et al. Clinical assessment of the cancer diagnostic value of prostatic zinc: A comprehensive needle-biopsy study. The Prostate. 2008;68(9):994-1006. https://doi. org/10.1002/pros.20766

25. Garland M, Morris J, Rosner B, Stampfer M, Spate V, Baskett C, et al. Toenail trace element levels as biomarkers: Reproducibility over a 6-year period. Cancer, Epidemiology, Biomarkers \& Prevention. 1993;2:1-13.

26. Charan J, Biswas T. How to calculate sample size for different study designs in medical research? Indian Journal of Psychological Medicine. 2013;35(2):121. https://doi. org/10.4103/0253-7176.116232

27. Sathian B, Sreedharan J, Baboo S, Sharan K, Abhilash E, Rajesh E. Relevance of Sample Size Determination in Medical Research. Nepal J Epidemiol. 2010;1:4-10.

28. Nwofor A, Oranusi C. Cancer of the Prostate: Experience at Nnewi, Southeast, Nigeria. Nigerian journal of clinical practice. 2004;7:65-8.

29. Ayodele J, Ajala I. Cobalt and Zinc in Toenails of Some Kano Inhabitants. Nigerian Journal of Basic and Applied Sciences. 201109 07;19(1). https://doi.org/10.4314/njbas.v19i1.69364

30. Kolonel Ln, Yoshizawa Cn, Hankin Jh. Diet And Prostatic Cancer: A Case-Control Study in Hawaii1. American Journal of Epidemiology. 1988 05;127(5):999-1012. https://doi. org/10.1093/oxfordjournals.aje.a114903

31. Leitzmann MF, Stampfer MJ, Wu K, Colditz GA, Willett WC, Giovannucci EL. Zinc Supplement Use and Risk of Prostate Cancer. JNCI Journal of the National Cancer Institute. 200307 02;95(13):1004-1007. https://doi.org/10.1093/ jnci/95.13.1004

32. Meyer F, Galan P, Douville P, Bairati I, Kegle P, Bertrais S, Estaquio C, Hercberg S. Antioxidant vitamin and mineral supplementation and prostate cancer prevention in the SU.VI.MAX trial. International Journal of Cancer. 2005;116(2):182-186. https://doi.org/10.1002/ijc.21058

33. Karimi G, Shahar S, Homayouni N, Rajikan R, Bakar NFA, Othman MS. Association between Trace Element and Heavy Metal Levels in Hair and Nail with Prostate Cancer. Asian Pacific Journal of Cancer Prevention. 2012 09 30;13(9):42494253. https://doi.org/10.7314/apjcp.2012.13.9.4249

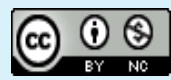

This work is licensed under a Creative Commons AttributionNon Commercial 4.0 International License. 